Indonesian Journal of Nutrition and Dietetics Vol. 5, Issue 2, 2017: 88-92
Available online at: http://ejournal.almaata.ac.id/index.php/IJND DOI : http://dx.doi.org/10.21927/ijnd.2016.5(2).88-92

\title{
Dietary fiber and carbohydrate contents of gathotan and gathot as functional food for people with diabetes mellitus
}

\author{
Puspita Mardika Sari', Desty Ervira Puspaningtyas ${ }^{1}$, Rio Jati Kusuma² \\ ${ }^{1}$ Department of Nutrition, Universitas Respati, Yogyakarta, Indonesia \\ ${ }^{2}$ Department of Health Nutrition, Universitas Gadjah Mada, Yogyakarta, Indonesia \\ *Corresponding author : puspitamardika@gmail.com \\ Article was presented in 1st International Seminar on Biotechnology at October 7th, 2017
}

\begin{abstract}
Background : Gathotan and gathot are Indonesian cassava traditional fermented food from Gunungkidul, Yogyakarta. These fermented foods may be considered as an important component of a functional-foods based diet for management of type 2 diabetes mellitus (DM). Previous study found that gathotan and gathot had low glycemic index (GI). Fermentation processed using fungi and bacteria had potency to give many beneficial effects, such as prebiotic that gives contribution on the forming of short chain fatty acid (SCFA). SCFA gives many beneficial effects on metabolism and prognosis on type 2 DM. However, there have been no study on the potency of gathotan and gathot as dietary fiber sources.

Objectives: This study was designed to examine carbohydrate and dietary fiber content in gathotan and gathot as functional food for people with DM.

Methods: Gathotan was made by spontaneous fermentation. Gathot was made by soaking overnight of gathotan, then steaming and drying. Carbohydrates content was calculated by using "carbohydrate by diference" method. Dietary fiber content was analyzed by using enzymatic gravimetri method.

Results: The highest carbohydrate content was found in cassava (81.13\%), followed by gathotan (68.32\%), and gathot (39.03\%), respectively. The highest dietary fiber content was found in gathot (17.36\%), followed by gathotan (14\%), and cassava (8.61\%) respectively.

Conclusion: Fermentation process of cassava to be gathotan and gathot are potential to decrease carbohydrate, but increase in dietary fiber content.
\end{abstract}

KEYWORDS: gathotan, gathot, functional food, diabetes mellitus.

\section{INTRODUCTION}

Gathotan and gathot are traditional cassava based fermentation products that are typical food from Gunungkidul area, Yogyakarta $(1,2)$. Gathotan and gathot differ in terms of processing. Gathotan was made from dried cassava and fermented by mushrooms / molds to produce products that were blackish, then dried again. The dominant microbes in the gathotan fermentation process is hypomycetic spore-forming fungi such as Rhizopus oryzae and Aspergillus flavus on the surface. The microbes grown in the center of the bulb are dominated by Lasiodiplodia theobromae which gives the characteristic black color of gathotan (2). Gathot was a typical gathotan processed food product with a unique chewy texture. Gathot was made from dried gathotan and then immersion, size reduction, and steaming becomes gathot (3). The process of re-immersion was a further fermentation process involving lactic acid bacteria.

The process of cassava fermentation into gathotan and gathot allegedly play a improves the quality of nutrients and potentially to be utilized as functional food for mellitus (DM). Previous research has found that cassava fermentation to gathotan and gathot has been shown to provide many advantages such as lowering aflatoxin content, producing antioxidant compounds, and reducing glycemic index in gathotan and gathot (4.1). Nevertheless, the content of dietary fiber and carbohydrates that correlate with the potential of prebiotics has never been studied. Prebiotics play an important role in overcoming metabolic disorders in obesity and diabetes mellitus (DM) type 2 through 
selective gastrointestinal microelectomy stimulation mechanisms that spur the formation of short chain fatty acids (SCFA) (5).

Therefore, this study aimed to analyze the content of dietary fiber and carbohydrates in gathotan and gathot, as a preliminary study of the development of these fermented foods as a functional food for DM.

\section{MATERIALS AND METHODS}

This research was a laboratory experimental study with observational study design. Cassava and dried gathotan raw materials wereobtained from local farmers and craftsmen in Prambanan, Piyungan and Wonosari markets. Gathot was made by soaking gathotan for $2 \times 24$ hours, steamed for 30 minutes, and dried by cabinet dryer. Cassava, gathotan, and gathot were bundled with grinder and sieved with 40 mesh size. Carbohydrate content analysis was conducted at Faculty of Agricultural Technology Universitas Gadjah Mada. The analysis of dietary fiber was carried out in Laboratory of Chemix Pratama, Bantul, Yogyakarta.

Carbohydrate content of cassava flour, gathotan and gathot was calculated by carbohydrate by diference method with formula "\%Carbohydrate $=100 \%$ (\%ash+\%water+\%protein+\%fat)".
Water and ash levels were determined by thermogravimetric method, protein content by Kjeldahl method, and fat content by Soxhlet method. Levels of dietary fiber were analyzed by enzymatic gravimetric method (AOAC method 32.1.17 (45) .Analysis of dietary fiber on cassava, gathotan, and gathot and carbohydrate content in cassava was done by 2 replications, then the data analysis was done descriptively Gathot was made through fermentation process continued from gathotan so that carbohydrate content was analyzed by paired t-test sample.

\section{RESULTS}

Analysis of dietary fiber and crude fiber content showed that the highest fiber content of both soluble and insoluble fiber was found in gathot, followed by gathotan and lowest in cassava (presented in Figure 1).

From the results of statistical analysis with Paired sample T-test, obtained information that there were differences in carbohydrate levels significantly between gathotan and gathot. The carbohydrate levels among the three samples showed that the highest carbohydrate content was in cassava, followed by gathotan and gathot (presented in Figure 2).

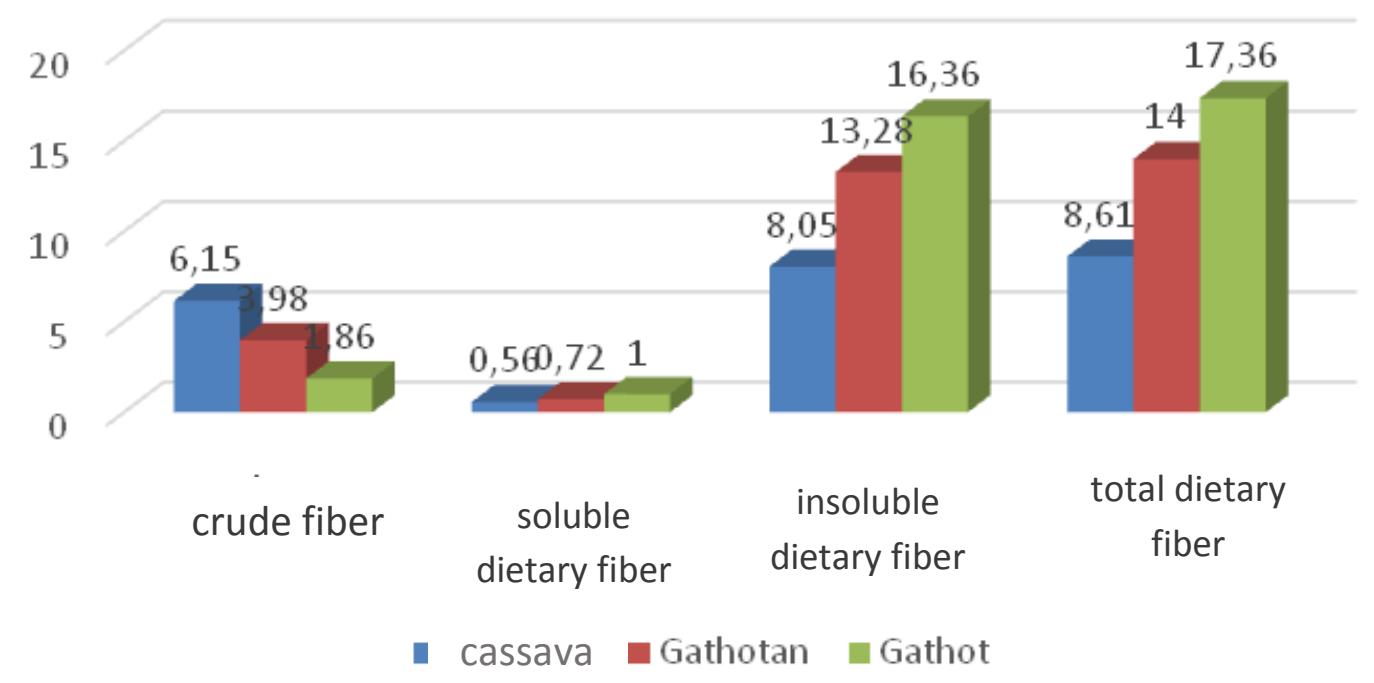

Figure 1. Fiber Fibers Content in Gathot, Gathotan and Cassava 

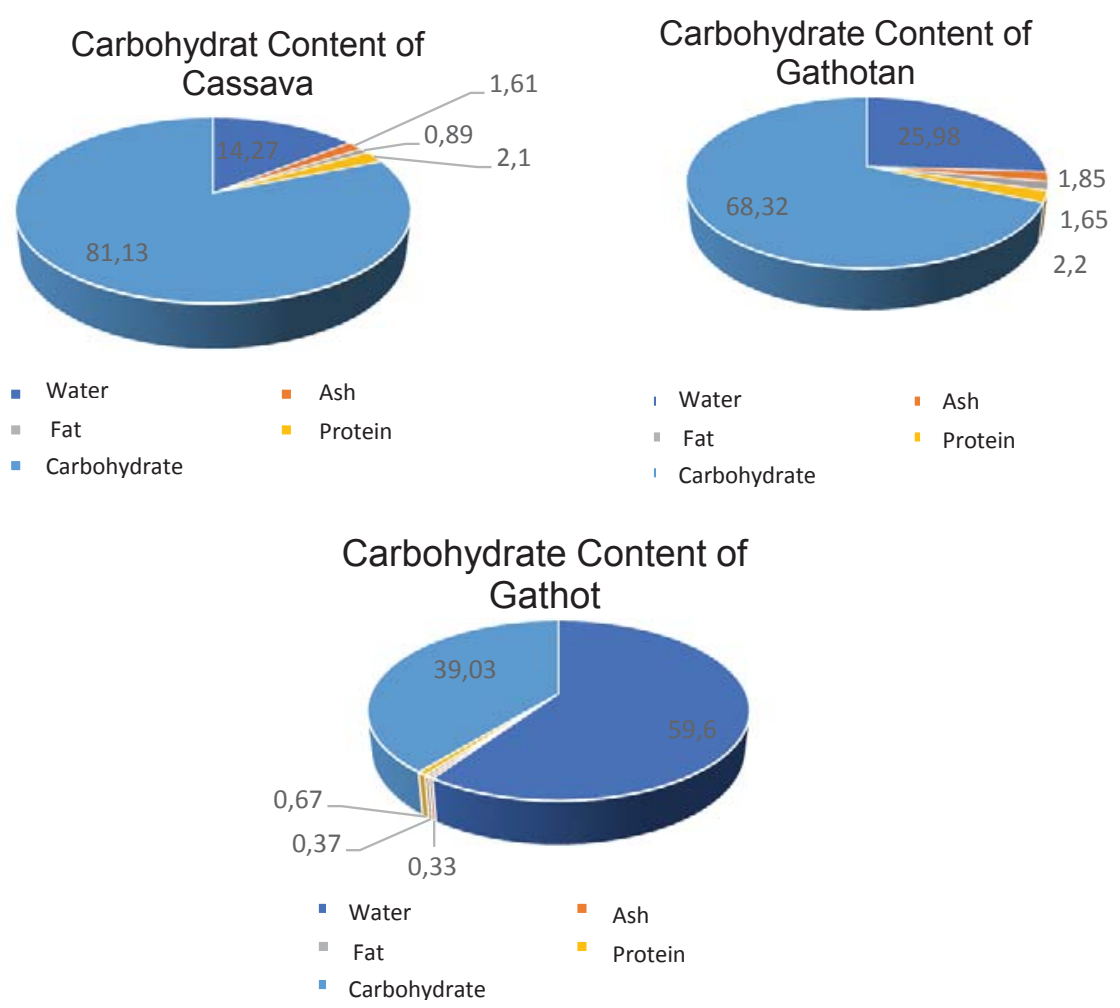

Figure 2. Carbohydrate and Proximate Content of Gathot, Gathotan and Cassava

\section{DISCUSSION}

Low carbohydrate levels and high levels of dietary fiber in gathotan and gathot compared with cassava are probably due to enzymatic processes during fermentation. The process of cassava fermentation into gathotan and gathot involving the fungus Botryodiplodia theobromae causes degradation of starch compound. This is thought to be due to the activity of the $\beta$-glucosidase enzyme in $B$. theobromae which can break down starch compounds to form glucose and dextrin (4).

In the fermentation process is likely to occur hydrolysis of carbohydrate compounds (starch, cellulose, andpectin) into organic acid compounds $(1,3)$. Amylolytic lactic acid bacteria in the natural fermentation process can produce extracellular enzymes such as amylase and pululanase which can hydrolyze some starchy starch into simple sugars, other oligosaccharides or dextrin, and some undigested resistant starch 3 .

The possibility of changing the type of carbohydrate (especially the formation of oligosaccharides compound, dextrin, and some undigested resistant starch) during the fermentation process of cassava to gathotan and gathot allowed the decrease of glycemic index in gathotan and gathot (4). The relatively low glycemic index in gathotan and gathot made these two local food products as one of the alternative food choices for diabetics. Foods with a low glycemic index could improve glycemic controls that are known to maintain the condition of diabetic patients and prevent complications resulting from diabetes mellitus (6.7).

The content of dietary fiber in gathotan and gathot has the potential to provide benefits for people with diabetes. The higher the fiber content of food, the more controlled postprandial blood sugar levels. Increased fiber intake was associated with improved insulin secretion and sensitivity. Dietary fiber intake was also associated with glycemic control, decreased hyperinsulinemia, and decreased plasma lipid (6). Fiber intake was proven to reduce fasting glucose (8.9) and lowered hemoglobin 
(HbA1c) levels (9). A good fiber intake can reduce the risk of death in individuals with diabetes mellitus (10).

Fiber content in gathotan and gathot also correlated with the potential of prebiotics. Prebiotics are undigested polysaccharides that play a role in supporting growth and microflor activity of digestive and proven beneficial effects in metabolism. Prebiotics are known to be inulin and various types of fruktooligosakarida that play a role in increasing the growth of bacteria such as Bifidobacteria or Lactobacilli (11). In addition, prebiotics also contributed to weight loss, body fat, and the size of fat cells by regulating the intake of food used by the body $(12,13)$. Prebiotics contributed favorable effects to patients with metabolic syndrome by significantly reducing post-prandial and insulin levels significantly (14).

Prebiotics play an important role in overcoming metabolic disorders in obesity and diabetes mellitus (DM) type 2 through selective gastrointestinal microelectomy stimulation mechanisms that spur the formation of Short Chain Fatty Acids (SCFA) (5). SCFA compounds (acetate, propionate, and butyrate) play a role in energy homeostasis and metabolism, as well as in adipose tissue modulation, skeletal muscle, and liver function, contributing to improved glucose homeostasis and insulin sensitivity (15). In vivo studies in mice found that oral administration of butyrate had an increased effect of insulin sensitivity and increased the energy expenditure through improved mitochondrial function (16). Continuous inulin prebiotic administration showed in increasing the composition and metabolism of the gastrointestinal microbes and produced the production of SCFA(17). Clinical studies also shown that prebiotic administration is able to prevent the pathogenesis of type 2 diabetes (14).

Prebiotic compounds generally consist of oligosaccharide compounds such as inulin, raffinose, fruktooligosakarida, galaktooligosakarida. These compounds can be selectively metabolized by bacteria in the gastrointestinal tract so as to help maintain intestinal microflora balance, promote beneficial bacteria, and can not be metabolized by pathogenic bacteria (18). Prebiotics affect the microflora of the gastrointestinal tract by stimulating the growth of probiotics especially the Lactobacillus bacteria group, increasing antimicrobial activity of Lactobacillus (producing bacteriocoses) in the fight against pathogenic bacteria such as Listeria monocytogenes and Enterococcus faecalis (19).

\section{CONCLUSIONS AND RECOMMENDATIONS}

The results of this study indicated that the process of cassava fermentation into gathotan and gathot potentially reduced carbohydrate levels and increase levels of dietary fiber. However, further research is needed to examine the potential of prebiotics and metabolic mechanisms of gathotan and gathot to be developed as functional food for people with DM.

\section{ACKNOWLEDGMENT}

This research was supported by Grants for Indonesian Lecturers (RISTEK-DIKTI), funded by the Indonesian Ministry of Research, Technology, and Higher Education with contract number: 056 / HB-LIT / IV / 2017.

\section{REFERENCES}

1. Oktaviana, Saputri R, Pangesthi LC. Pengaruh Substitusi Puree Gatot Instan Terhadap Sifat Organoleptik Roti Manis. E-journal Boga 2014; 03 (03); 141-150

2. Purwandari U, Nava N, Hidayati D. Modeling and Optimising the Growth of Lasiodiplodia theobromae During Gathotan Fermentation. Microbiology Indonesia 2014b; 8(3); 112-120.

3. Astriani. Karakterisasi Gatot Terfermentasi Oleh Isolat Indigenus Gatot Singkong (Rhizopusoligosporus) dan (Lactobacillus manihotivorans). Skripsi Universitas Jember; 2015.

4. Purwandari U, Tristiana GR,Hidayati D.Glutenfree noodle made from gathotan flour: antioxidant activity and effect of consumption on blood glucose level". International Food Research Journal2014a; 21(4); 1629-1634. 
5. Everard A, Cani PD, Diabetes, obesity and gut microbiota. Best Practice \& Research Clinical Gastroenterology2013; 27; 73-83

6. Franz, Marion J. Medical Nutrition Therapy for Diabetes Mellitus and Hypoglycemia of Nondiabetic Origin dalam Krause's Food \& Nutrition Therapy Edition 122008; Canada: Saunders Elsevier

7. Katsilambros N, Dimosthenopoulos C.Diabetes dalam Clinical Nutrition in Practice.2010; Malaysia: Wiley-Blackwell

8. Manalu M. Hubungan Konsumsi Energi, Serat Dan Pengetahuan Diit Diabetes Mellitus Dengan Kadar Glukosa Darah Puasa Penderita Diabetes Mellitus Tipe 2 Di RSU Kota Semarang. Artikel Penelitian Universitas Diponegoro 2007.

9. Post, Robert E, Arch G M, Dana EK, Kit NS. Dietary Fiber for the Treatment of Type 2 DiabetesMellitus: A Meta-Analysis. J Am Board Fam Med 2012; 25;16 -23.

10. Burger KNJ, Joline WJB, Yvonne TvdS, Ivonne S, Annemieke M, Spijkerman W, et al. Dietary Fiber, Carbohydrate Quality and Quantity, andMortality Risk of Individuals with Diabetes Mellitus. PlosOne 2012;7:8

11. Franz MJ. Medical Nutrition Therapy for Diabetes Mellitus and Hypoglycemia of Nondiabetic Origin dalam Krause's Food \& Nutrition Therapy Edition 122008; Canada: Saunders Elsevier

12. Neyrinck AM, Possemiers S, Druart C, Van de Wiele T, De Backer F, Cani PD, et al. Prebiotic effects of wheat arabinoxylan related to the increase in bifidobacteria, Roseburia and Bacteroides/Prevotella in diet-induced obese mice. PLoS One 2011; 6: e20944
13. Parnell JA, Reimer RA. Prebiotic fibres dosedependently increase satiety hormones and alter Bacteroidetes and Firmicutes in lean and obese JCR: LA-cp rats". Br J Nutr 2012; 107;601-613

14. Kellow NJ, Coughlan MT, Svige GS, Reid CM. Effect of dietary prebiotic supplementation on advanced glycation, insulin resistance and inflammatory biomarkers in adults withprediabetes: a study protocol for a double-blind placebo-controlled randomised crossover clinical trial". BMC Endocrine Disorder 2014; 14; 55.

15. Canfora, EE, Jicken JW, Blak EE. Shortchain fatty acids in control of body weight and insulin sensitivity. Nature Reviews Endocrinology2015;11;577-591

16. Hartstra AV., Kristien ECB, Fredrik B, Max N. Insights Into the Role of the Microbiome in Obesity and Type 2 Diabetes. Diabetes Care 2015;38(1);159-165

17. Wiele TV, Boon N, Possemiers S, Jacobs H, Verstraete W. Prebiotic effects of chicory inulin in the simulator of the human intestinal microbial ecosystem". FEMS Microbiology Ecology 2004;51;143-15

18. Gibson G, Roberfroid M.. Dietary Modulation of the Human Colonie Microbiota: Introducing the Concept of Prebiotics. The Journal of Nutrition 2010; 1401-1412

19. Munoz M, Mosquera A, Almecigadiaz CJ, Melendez AP, Sanchez OF. Fructooligosaccharides metabolism and effect on bacteriocin production in Lactobacillus strains isolated from ensiled corn and molasses. Anaerobe2012; 18; 321e330 